\title{
The knowledge-based view of the firm and its theoretical precursor
}

\section{Carla Curado}

ISEG - Technical University of Lisbon

Rua Miguel Lupi, 20

1249-078 Lisbon, Portugal

Fax: (+351) 213922808

E-mail: ccurado@iseg.utl.pt

\author{
Nick Bontis* \\ DeGroote School of Business \\ McMaster University \\ DSB \#207, 1280 Main Street West \\ Hamilton, Ontario L8S 4M4, Canada \\ Fax: (905) 5218995 \\ E-mail: nbontis@mcmaster.ca \\ *Corresponding author
}

\begin{abstract}
The knowledge-based view of the firm is a recent extension of the Resource-Based View (RBV) of the firm and provides a strong theoretical underpinning for the organisation learning and intellectual capital researchers. Knowledge is considered to be a special strategic resource that does not depreciate in the way traditional economic productive factors do. The nature of most knowledge-based resources is mainly intangible and dynamic, allowing for idiosyncratic development through path dependency and causal ambiguity, which are the basis of the mechanism for economic rent creation in the Knowledge-Based View (KBV) of the firm. Future implications that emerge from these characteristics as they relate to learning organisations are presented at the end of the paper.
\end{abstract}

Keywords: Resource-Based View (RBV); Knowledge-Based View (KBV); knowledge resources; intangible assets; economic rent creation.

Reference to this paper should be made as follows: Curado, C. and Bontis, N. (2006) 'The knowledge-based view of the firm and its theoretical precursor', Int. J. Learning and Intellectual Capital, Vol. 3, No. 4, pp.367-381.

Biographical notes: Carla Curado has a Master's in Economic Sociology of the Firm and a PhD in Management from the University of Lisbon.

Dr. Nick Bontis is Associate Professor of Strategy at the DeGroote Business School, McMaster University. He received his PhD from the Ivey Business School, University of Western Ontario. He has published extensively in a variety of academic journals and has completed three books. He is recognised the world over as a leading professional speaker and consultant in the field of intellectual capital, knowledge management and organisational learning. 


\section{Introduction}

Although considered a relatively new perspective within the field of strategic management, the Knowledge-Based View (KBV) of the firm has spawned a burgeoning amount of research growth in the field of organisational learning (Bapuji and Crossan, 2004). In addition, the fields of knowledge management and intellectual capital have also garnered a strong recognition and representation in academia, business, and government (Bontis, 2002; Choo and Bontis, 2002). A recent meta-analysis of the knowledge management and intellectual capital literature demonstrates that this research field is exploding, and that the total number of publications is predicted to exceed 100000 individual contributions by the year 2010 (Serenko and Bontis, 2004). The KBV of the firm provides a conceptual lense for a variety of disciplines including human resources, organisational behaviour, management information systems and innovation (Bontis, 2001). By employing a KBV perspective, researchers can draw novel implications related to firms that thrive in an economy that supports intangible asset development.

The purpose of this paper is to provide a concise literature review on how the KBV of the firm was developed and how it relates to the intangible assets of an organisation.

\section{The resource-based view of the firm}

The foundations of the Resource-Based View (RBV) of the firm can be found in the work of Penrose (1959) who conceived the firm as an administrative organisation and a collection of productive resources, both physical and human. Physical resources (e.g., land and equipment), as well as human resources, can provide the firm with a variety of value-added services. The same resources can be put to use in different ways according to the ideas of how to apply them. In this sense, there is a close relationship between the knowledge that people in the organisation retain and the services obtained from those resources. Hence, firms are really repositories of knowledge.

The RBV of the firm focuses specifically on the inside of the firm (i.e., its resources and capabilities) to explain the profit and value of the organisation (Penrose, 1980; Wernerfelt, 1984; Barney, 1991; Grant, 1991; Peteraf, 1993; Makhija, 2003). This theory is applied to explain differences in performance within an industry (Hoopes et al., 2003). The RBV of the firm postulates that differences in firm performance happen when organisations possess valuable resources that others do not have, allowing them to obtain a rent in its quasi-monopolist form (Wernerfelt, 1984).

The existence of capability heterogeneity within a population of firms is one of the principles of the RBV (Helfat and Peteraf, 2003). Organisations are heterogeneous entities characterised by their particular and unique resource bases (Barney, 1991; Nelson and Winter, 1982; Marr, 2004). The RBV of the firm presents an explanation for the heterogeneous competition based upon the premise that close competitors differ in an important and lasting way in their resources and capabilities (Helfat and Peteraf, 2003). This perspective recognises that the type, magnitude and nature of resources and capabilities are important determinants in their capacity to generate profit (Amit and 
Shoemaker, 1993). By accumulating resources with rent-yielding potential the firm may increase the amount of rents generated, and therefore subsequent profits (Szulanski, 2003).

The process of resource accumulation is considered to be a reflection of innovative entrepreneurial activities. Profits can only emerge from these activities if resource accumulation costs are inferior to the rents that those resources might actually produce (Peteraf, 1993). Considering the RBV of the firm, an organisation is a collection of unique competencies and capabilities influencing its evolution and its strategic growth options (Barney, 1991; Dierickx and Cool, 1989; Winter, 1987). The nature of rents generated in the perspective of the RBV is Ricardian (Barney, 1986a; 1997; Conner, 1991; Montgomery and Wernerfelt, 1988; Peteraf, 1993; Wernerfelt, 1984; Makadok, 2001; Teece et al., 1997), this means that the choice of the resources is the main mechanism influencing the generation of the economic rent (Makadok, 2001). The Ricardian logic explains the heterogeneity of firm performance as a consequence of organisations owning resources with different productivities. In this sense one should be led to ask: How do organisations acquire resources with heterogeneous productivities? Barney (1986a; Makadok, 2001) answers that question this way: the organisation should apply a superior capacity to choose resources at the resource markets. These capacities will traduce in most precise and better well define expectations of the future value of resources, than those presented by other participants in the resource market (Makadok, 2001).

A consequence of this Ricardian RBV of the firm is that the mechanism for economic rent creation acts 'before' the acquisition of resources. The firms processing the superior capacities to identify which are the winning and the loosing resources will be able to acquire the former ones and avoid the last ones. Considering this mechanism, every choice happens 'before' the acquisition of the resources. A corollary it is then possible to establish: the capacity to choose resources may affect the economic performance of the firms even when they do not acquire the resources (Makadok, 2001).

The RBV of the firm is a suitable approach to understand competitive dynamics (DeNisi et al., 2003). Since Barney's (1991) paper in the early 1990s, several authors have approached the firm and its strategy from a resource-based perspective. Barney presented a method of analysis to identify the characteristics of firm resources that are able to generate sustained competitive advantage (Hoskisson et al., 1999). A decade later, Barney (2001b) further developed his work contrasting the RBV of the firm to other theories. Many papers in the field of strategic management have leveraged his groundbreaking conceptual work (Barney, 2001a).

The RBV of the firm is a strategic line of thought that analyses the organisation's strengths and weaknesses. The organisation's attributes that allow it to conceive of and implement value-creating strategies are resources. According to Barney (1991), firm resources can either be: physical, human, or organisational. Resources can also be tangible, or intangible (Bontis, 1998; Hoskisson et al., 1999; Hannes and Fjeldstad, 2000; Gupta and Roos, 2001; Spanos and Lioukas, 2001; Mathews, 2003). The resources, assets and capabilities the firm possesses are used to build its competitive advantage and, as a consequence, economic wealth (Dess et al., 1995). The resources and capabilities, tangible and intangible, generate economic returns to the firm (Amit and Shoemaker, 1993). 
The RBV of the firm considers that resources are not limited to the traditional economic productive factors; they also include socially complex resources, such as interpersonal relationships within firm managers, the firm's culture, or its reputation near the suppliers or clients (Barney, 1991). This is often referred to as relational capital (Bontis, 1999). Physical resources may originate returns above average levels, but are the intangible resources, developed through a unique historical sequence and having a socially complex dimension, that are able to create and sustain competitive advantage of the firm (Makhija, 2003). The RBV of the firm recognises the strategic importance of social and behavioural interactions in the conceivability of, the choice, and the implementation of the organisation's strategies (Barney, 1986b; Barney and Zajac, 1994). Intangible resources can hardly be changed, except in the long term (Teece et al., 1997). These intangible resources are frequently found in the organisation in the form of tacit knowledge (Makhija, 2003).

Resources are the basis of this theory and they explain the differences in performance between firms, as a consequence firms that possess certain competitive advantages obtain higher returns. On the other hand, resources are the basis of the organisation's strategy and are used to implement it. Having this in mind we are able to observe the joint effect of resources and strategy in the organisation's returns (Hitt et al., 2001). According to Barney (1991), following other authors, firm resources are the assets, the capabilities, the organisational processes, the firm attributes, the information, and the knowledge.

Following the RBV of the firm we should consider the conditions set by Barney (1991): resource heterogeneity - necessary but not sufficient to obtain a sustainable competitive advantage - and resource immobility - through the retention of resources in certain firms unless imitations can be developed (see Dess et al., 1995; Mata et al., 1995; Alvarez and Barney, 2001 for a more comprehensive review).

Barney (1991) considers that firm resources can be classified into three categories: physical capital resources, human capital resources and organisational capital resources. According to Barney (1991) there are certain conditions that resources must present to enable the firm to sustain its competitive advantage: rareness, value, imperfect imitability and non-substitutability. We find these conditions are still respected in recent literature (see Hoopes et al., 2003; King and Zeithaml, 2003; or Wiklund and Shepherd, 2003). Competitive advantage does not emerge from industry dynamics, but from the processes of accumulation and utilisation of resources within the firm, in other words, it is the result of the way the firm uses what it has got (Roos et al., 2001). The strategic value of the organisations resources and capabilities can be increased by the difficulty of buying, selling, imitating or substituting them. Invisible assess, like tacit knowledge or trust, can not be transacted or easily replicated by competitors, as they are usually founded in organisational history (Amit and Shoemaker, 1993).

Human capital presents a certain degree of mobility, but the capabilities employees possess can be valuable to a firm and not so for another firm, or competitor. Certain capabilities, based upon the tacit knowledge of the firm, are only valuable when integrated with other individual capabilities specific to that particular firm, and that capacity of being complementary is immobile (Hitt et al., 2001). The RBV of the firm establishes the possibility for researchers to link the resources of the firm to its sustained competitive advantage. This theory identifies the existence of rivalry between firms that present differences in efficiency due to resources heterogeneity. Industry equilibrium is based on the productivity differentials between firms. The RBV of the firm considers that the differences in efficiency between firms within the same industry persist due to the 
difficulty in imitating the resources each firm possesses (Seth and Thomas, 1994), this means that systematic variations in profit and performance have their origins in particular firm factors (Amit and Shoemaker, 1993).

\section{From the resource-based to the knowledge-based view of the firm}

It is largely accepted that the KBV of the firm is a recent extension of the RBV of the firm (Grant, 1996a; Roos, 1998; Hoskisson et al., 1999; Sveiby, 2001; Bontis, 2002; De Carolis, 2002; Huizing and Bouman, 2002; Balogun and Jenkins, 2003). The KBV of the firm considers knowledge as the most important strategic resource and, in that sense, this perspective is and extension of the RBV of the firm (De Carolis, 2002).

The recent extension of the RBV, the KBV, is accepted to be adequate to the present economic context (Drucker, 1993; Sirois, 1999; Stewart, 1997; Garud and Kumaraswamy, 2002; Grant, 2002; Guthrie, 2001; Mathews, 2003). In this context, intangible assets are highly valued and considered critical intellectual capital assets (Bontis et al., 1999; Petrick et al., 1999; Bontis et al., 2000; Eustace, 2000; Barney, 2001b; Hitt et al., 2001; Grant, 2002; Bontis and Fitz-enz, 2002; Mathews, 2003; Bontis, 2004). The interpretation of knowledge as a resource establishes the theoretical connection between the RBV and the KBV (Ariely, 2003; Malerba and Orsenico, 2000). Competition based upon capabilities, and the notion of increasing returns was first suggested by Penrose (1959) and then further explored by Wernerfelt (1984) and Rumelt (1984) who are considered to be the founding developers of the modern RBV of the firm (Foss, 1997).

The KBV of the firm is an extension of the RBV of the firm because it considers that organisations are heterogeneous entities loaded with knowledge (Hoskisson et al., 1999). The resource base of the organisation increasingly consists of knowledge-based assets (Roos et al., 1997; Stewart, 1997; Sveiby, 2001; Marr, 2004). The logic of the RBV of the firm suggests that unique characteristics of the intangible resources (especially knowledge) should determine the focus of research (Rouse and Daellenbach, 2002). Knowledge resources are particularly important to ensure that competitive advantages are sustainable, as these resources are difficult to imitate and are the foundation for sustainable differentiation (Wiklund and Shepherd, 2003).

The global economy is witnessing a structural change in the productive paradigm (Carneiro, 2003). The change from manufacture to services in the majority of developed economies is based on the manipulation of information and symbols and not on the use of physical products (Fulk and DeSanctis, 1995). The RBV of the firm literature justifies the existence of differences in performance between organisations as a consequence of knowledge asymmetries (i.e., capabilities and competences). As a result, an important $\mathrm{KBV}$ proposition states that the organisation exists to create, transfer and transform knowledge into competitive advantage (Kogut and Zander, 1992). Nevertheless, transferring knowledge through the organisation can be difficult. Stickiness reflects the presence of internal factors that enable the true achievement of competitive advantage. Stickiness also hinders the appropriation of rents from existing knowledge assets (Szulanski, 2003). 
Conner and Prahalad (2002) argue that the KBV of the firm lies with the RBV. According to these authors there is an emerging strategic management literature on the RBV that points out that knowledge as the basis for competition. The RBV of the firm should incorporate the temporal evolution of its resources and the capabilities that sustain competitive advantage (Helfat and Peteraf, 2003), and that was achieved by the concept of 'dynamic capabilities'.

The Ricardian perspective of rent creation adopted by the RBV of the firm is challenged by the Shumpeterian perspective of the dynamic capabilities vision (Amit and Shoemaker, 1993; Dierickx and Cool, 1989; Mahoney, 1995; Nelson and Winter, 1982; Teece et al., 1997; Makadok, 2001). This vision of dynamic capabilities enlightens the importance of an alternative rent creation mechanism - capability building - which is different from resource choosing Makadok (2001). Teece et al. (1997) present a clear distinction between the two perspectives: the RBV and the dynamic capability view; the former is mostly dependent on resources and presents a Ricardian rent creation. On the other hand, the dynamic capability view is strongly related to processes and paths, representing Schumpeterian rent creation.

Considering that the dynamic capabilities concept made an extension to RBV (Malerba and Orsenico, 2000), we can make a logical deduction and admit that the influence of the capability development mechanism will affect the KBV of the firm. Dynamic capabilities have the capacity to reconfigure, redirect, transform, shape and integrate central knowledge, external resources and strategic and complementary assets. They will allow the firm to respond to the challenges presented by the Schumpeterian competitive world, made of competition and imitation, changing so fast and pressured by temporal factors (Teece et al., 1997). Petrick et al. (1999) present the intangible assets (both individual, such as leadership, and social, such as organisational reputation) as being the basis for sustained competitive advantage. Following a RBV approach, the central capabilities (such as the capabilities to define and solve organisational problems) are the base for the specific competitive advantage of the firm (Lei et al., 1996). Present management literature strongly points out capabilities and competences as the basis for the competitive advantage of the firm (Amit and Shoemaker, 1993).

\section{The knowledge-based view of the firm}

The economic change of material-based production to information-based production created a revaluation of firms and their workers. Increasingly we find knowledge workers at the core of organisation functions (e.g., concept and technology designers, as well as finance and management people). Other individuals are considered to be in the firm's periphery, as a consequence their responsibilities change permanently and they are defined by the tasks they perform at the moment. This way, a new differentiation in labour arises (Child and McGrath, 2001).

Many firms consider that to act with efficacy in today's economy, it is imperative for them to become a knowledge-based organisation. But few understand what that means, and how to make the changes necessary to achieve it. Perhaps the most common mistake firms do is considering that the higher the knowledge content of their products and services, the more close they are to being a true knowledge-based organisations. But products and services are only the visible and tangible reality they present to their clients - the tip of the iceberg. As in real icebergs, the largest reality that allows the firm to 
produce is located below the surface of the water, hidden in the intangible assets of the organisation, and it entails the knowledge of what the firm does, how it is done, and why it is done that way (Zack, 2003).

The KBV of the firm is consistent with the approach that organisations are cultural artefacts (Balogun and Jenkins, 2003). As such, they learn through activities and adapt over time. Organisational learning allows the firm to acquire, to change and to preserve its organisational capabilities (Cook and Yanow, 1995). Culture is most repeatedly defined after Schein (1985; Balogun and Jenkins, 2003), as a set of assumptions and beliefs held in common and shared by members of an organisation, or as shared beliefs and knowledge by Nonaka and Takeuchi (1995). Organisational culture is, in each moment, the stock of knowledge, coded or not, integrated in patterns and recipes of action to be taken before certain situations (Bontis et al., 2002). Organisational routines often make knowledge become tacit and embedded (Balogun and Jenkins, 2003). A routine consists of behaviour that is learned, highly patterned, repeated and founded, even if only partly, in tacit knowledge (Winter, 2003).

Following Nonaka (1991) the only true lasting competitive advantage is knowledge and thus we have conceptualised the knowledge-based organisation (Blackler, 2002) and the knowledge-based advantage (McEvily and Chakravarthy, 2002). These authors recognise that non-observable factors have an impact on firm performance. Those factors, as management capabilities and competences, technical knowledge or tacit organisational routines, may turn out to be the main determinants of firm performance (Dess et al., 1995).

The strategic management literature now generally equates competitive advantage in a way that it associates firm performance variation to intangible factors (Rouse and Daellenbach, 2002). Apart from natural resource monopolies, intangible resources present a superior probability to produce competitive advantage, as they are generally rare, socially complex, and hardly imitable (Hitt et al., 2001). In the same sense, it is appropriate to point out that there is a knowledge management literature that associates superior knowledge bases, resulting from organisational learning, to superior firm performances (Senge, 1990; Garvin, 1998; Bontis et al., 2002), as well as presenting differences in knowledge inventories as the basis of competitive advantage (Miller, 2002). A superior knowledge base can be associated with higher strategic flexibility and faster reaction to environment changes (Grant, 1996b; Volberda, 1996; Umemoto, 2002).

Through the use of dynamic capabilities, organisations can integrate, build and reconfigure their internal and external capacities to face fast changing environments (Teece et al., 1997). Organisational capabilities emerge over time through a process of organisational learning (Levitt and March, 1988; Szulanski, 2003). The learning organisation is a firm that purports to having established organisational learning capabilities. Organisational learning capabilities are considered to be the most strategically important ones to create and sustain competitive advantage (DeNisi et al., 2003). Superior talent is recognised to be the main creator of sustained competitive advantage in high performance firms (Hiltrop, 1999) and the capacity to learn faster than competitors is considered to the only sustained competitive advantage (Geus, 1988). This dynamic capability builds up over time a historical or path dependency (Collis, 1991; Winter, 1987; Lei et al., 1996), creating causal ambiguity (i.e., creating barriers to imitability and making it very difficult for other firms to recreate the unique historical evolution each organisation develops). 
Capabilities and capacities lead to superior sustained performances because they are specific to each organisation (i.e., they are temporarily immobile and unique to that firm), valuable to clients, non substitutable and hard to imitate (Rugman and Verbeke, 2002; Blackler, 2002). The replication of organisational routines, for example, is a very difficult and expensive process because replication itself is an organisational capability only developed through execution (Winter and Szulanski, 2002). The tacit, specific and complex knowledge that the organisation develops through replication generates long lasting advantages (McEvily and Chakravarthy, 2002). The firm absorbs internal and external knowledge, combines them with pre-acquired knowledge, and creates new intellectual capital (Cohen and Levinthal, 1990). Or, the organisation may enlarge its knowledge base through the new application of pre-existing knowledge in the firm (Szulanski, 2003; Gratton and Ghoshal, 2003). Even external, explicit knowledge, involving high acquisition costs to the firm and available to competitors simultaneously, combined with unique internal knowledge may result in new and exclusive knowledge advantages (Zack, 2002).

Knowledge intensive firms abandon formal structures and achieve coordination through social rewards and internal normative systems, instead of hierarchical control. Structure is a relevant factor to these organisations because when intensive knowledge firms grow they become more bureaucratic (Starbuck, 1992). Structure and control are the most addressed subjects by researchers analysing the 'productive process' that transforms knowledge into services (Rylander and Peppard, 2004). The dilemma between autonomy and control is frequently approached in the literature. Some arguments defend that the resolution of such dilemmas is better achieved through the application of cultural and normative processes, than through the utilisation of formal hierarchy and structure (Rylander and Peppard, 2004).

According to Sveiby (2001), knowledge-based strategic formulation is still limited by people's capability. Human experience might still be the limiting factor of a firm's success (von Krogh and Grand, 2002). In this 'new economy' (Grant, 2002), organisations become virtual, geographically dispersed, and highly dependent on computer-mediated communication. Firms negotiate almost exclusively in cyberspace and give extreme emphasis to learning and knowledge-based work (Markham, 1998). Organisations operate in a network independently from their geographic location, based upon the use of communication technologies (Blackler, 2002; Chauhan and Bontis, 2004).

\section{Conclusions}

Organisational knowledge presents a tremendous wealth creating potential. Contrary to traditional and finite production factors, knowledge can generate increasing returns, through its systematic use (Kim and Mauborgne, 1999). Knowledge can be used simultaneously in several applications and still it does not devaluate (King and Zeithaml, 2003). Organisational knowledge is such a marvellous substance, contrary to other resources, its utilisation, under different forms, increases, instead of decreases its value (Adler, 2002; Spender, 2002). Another implication of the KBV of the firm is the necessity for knowledge integration in the production process (Grant, 1997). The relationship between organisational knowledge and the firm's competitive advantage is 
influenced by its capacity to integrate and apply knowledge (Matusik and Hill, 1998). In this sense research has hanged its focus from the sources of advantages to the coordinating mechanisms of them (Grant, 2002).

A further application of the KBV has surfaced in the macro-economic literature related to the competitive advantage of nations. Cole (1998) considers that together with traditional resources, knowledge is a determining factor of a nation's competitiveness. According to a report by the OECD (1999; Cavalcanti, 2003) 55\% of the 1998 production of the world wealth was generated through knowledge resources. According to Boisot (2002), the recognition that knowledge contributes to the construction of national wealth and the development of a strong and competitive country goes back to the mercantilist era. In recent literature we find studies that describe the search for the knowledge-based foundations of national wealth (see Bontis, 2004; Jeong, 2002).

The variety of typologies, taxonomies and theories on organisational knowledge that are presented in the literature reveals a strong appetite for this type of research. However, there is still some lack of cumulative theoretical development as well as consistent use of constructs and measures. The diversity of methodologies reflects the embryonic state of the KBV field and its related sisters, knowledge management, intellectual capital and organisational learning.

A uniform theoretical body accepted by academia will be achieved through the persistence of researchers combining and integrating various theoretical perspectives in various contexts. But there is still no common language or unifying paradigm that gathers all that research together. Although there is much to be done, the following propositions are offered as a given:

- The KBV of the firm presents a Schumpeterian rent creation logic.

- Organisational learning plays a critical role in the sustainability of the competitive advantage resulting from the KBV of the firm.

- The nature of the most critical resources within the KBV of the firm is mainly intangible and dynamic.

- Idiosyncratic intangible assets developed through path dependency and causal ambiguity are the basis of the mechanism for economic rent creation in the KBV of the firm.

- The KBV of the firm considers a very special resource that does not depreciate, and can generate increasing returns even when its shared.

\section{References}

Adler, P. (2002) 'Market, hierarchy, and trust', in Choo and Bontis (Eds.) The Strategic Management of Intellectual Capital and Organizational Knowledge, New York: Oxford University Press.

Alvarez, S. and Barney, J. (2001) 'How entrepreneurial firms can benefit from alliances with large partners', Academy of Management Executive, Vol. 15, No. 1, pp.139-148.

Amit, R. and Shoemaker, P. (1993) 'Strategic assets and organizational rent', Strategic Management Journal, Vol. 14, pp.33-46. 
Ariely, G. (2003) 'Knowledge management as a methodology towards intellectual capital', Presented at the 3rd European Knowledge Management Summer School, San Sebastian, Spain, 7-12 September.

Balogun, J. and Jenkins, M. (2003) 'Re-conceiving change management: a knowledge-based perspective', European Management Journal, Vol. 21, No. 2, pp.247-257.

Bapuji, H. and Crossan, M. (2004) 'From questions to answers: reviewing organizational learning research', Management Learning, Vol. 35, No. 4, pp.397-417.

Barney, J. (1986a) 'Strategic factor markets: expectations, luck, and business strategy', Management Science, Vol. 32, No. 10, pp.1231-1241.

Barney, J. (1986b) 'Organizational culture: can it be a source of sustainable competitive advantage?', Academy of Management Review, Vol. 11, pp.656-665.

Barney, J. (1991) 'Firm resources and sustained competitive advantage', Journal of Management, Vol. 17, No. 1, pp.99-120.

Barney, J. (1997) Gaining and Sustaining Competitive Advantage, Reading, MA: Addison-Wesley.

Barney, J. (2001a) 'Is the resource-based "view" a useful perspective for strategic management research? Yes', Academy of Management Review, Vol. 26, No. 1, pp.41-56.

Barney, J. (2001b) 'Resource-based theories of competitive advantage: a ten-year retrospective on the resource-based view', Journal of Management, Vol. 27, pp.643-650.

Barney, J. and Zajac, E. (1994) 'Competitive organizational behavior: toward an organizationallybased theory of competitive advantage', Strategic Management Journal, Vol. 15, pp.5-9.

Blackler, F. (2002) 'Knowledge, knowledge work, and organizations: an overview and interpretation', in Choo and Bontis (Eds.) The Strategic Management of Intellectual Capital and Organizational Knowledge, New York: Oxford University Press, pp.47-64.

Boisot, M. (2002) 'The creation and sharing of knowledge', in Choo and Bontis (Eds.) The Strategic Management of Intellectual Capital and Organizational Knowledge, New York: Oxford University Press, pp.65-77.

Bontis, N. (1998) 'Intellectual capital: an exploratory study that develops measures and models', Management Decision, Vol. 36, No. 2, pp.63-76.

Bontis, N. (1999) 'Managing organizational knowledge by diagnosing intellectual capital: framing and advancing the state of the field', International Journal of Technology Management, Vol. 18, Nos. 5-8, pp.433-462.

Bontis, N. (2001) 'Assessing knowledge assets: a review of the models used to measure intellectual capital', International Journal of Management Reviews, Vol. 3, No. 1, pp.41-60.

Bontis, N. (2002) World Congress of Intellectual Capital Readings, Boston: Butterworth Heinemann KMCI Press.

Bontis, N. (2004) 'National intellectual capital index: a United Nations initiative for the Arab Region', Journal of Intellectual Capital, Vol. 5, No. 1, pp.13-39.

Bontis, N. and Fitz-enz, J. (2002) 'Intellectual capital ROI: a causal map of human capital antecedents and consequents', Journal of Intellectual Capital, Vol. 3, No. 3, pp.223-247.

Bontis, N., Crossan, M. and Hulland, J. (2002) 'Managing an organizational learning system by aligning stocks and flows', Journal of Management Studies, Vol. 39, No. 4, pp.437-469.

Bontis, N., Dragonetti, N., Jacobsen, K. and Roos, G. (1999) 'The knowledge toolbox: a review of the tools available to measure and manage intangible resources', European Management Journal, Vol. 17, No. 4, pp.391-402.

Bontis, N., Keow, W. and Richardson, S. (2000) 'Intellectual capital and the nature of business in Malaysia', Journal of Intellectual Capital, Vol. 1, No. 1, pp.85-100.

Carneiro, R. (2003) 'A Era do Conhecimento', in Silva and Neves (Orgs.) Gestão de Empresas na Era do Conhecimento, Lisboa: Edições Sílabo, pp.33-43.

Cavalcanti, M. (2003) 'Conhecimento e Desigualdade', in Silva and Neves (Orgs.) Gestão de Empresas na Era do Conhecimento, Lisboa: Edições Sílabo, pp.72-81. 
Chauhan, N. and Bontis, N. (2004) 'Organizational learning via groupware: a path to discovery or disaster?', International Journal of Technology Management, Vol. 27. Nos. 6-7, pp.591-610.

Child, J. and McGrath, R. (2001) 'Organizations unfettered: organizational forms in an information-intensive economy', Academy of Management Journal, Vol. 44, No. 6, pp.1135-1148.

Choo, C.W. and Bontis, N. (2002) The Strategic Management of Intellectual Capital and Organizational Knowledge, New York: Oxford University Press.

Cohen, W. and Levinthal, D. (1990) 'Absorptive capacity: a new perspective on learning and innovation', Administrative Science Quarterly, Vol. 35, No. 1, pp.128-152.

Collis, D. (1991) 'A resource-based analysis of global competition: the case of bearings industry', Strategic Management Journal, Vol. 12, pp.49-68.

Cole, R. (1998) 'Introduction', California Management Review, Vol. 40, No. 3, pp.15-21.

Conner, K. (1991) 'A historical comparison of resource-based theory and five schools of thought within the industrial organization economics: do we have a new theory of the firm?', Journal of Management, Vol. 17, No. 1, pp.121-154.

Conner, K. and Prahalad, C. (2002) 'A resource-based theory of the firm', in Choo and Bontis (Eds.) The Strategic Management of Intellectual Capital and Organizational Knowledge, New York: Oxford University Press, pp.103-131.

Cook, S. and Yanow, D. (1995) 'Culture and organizational learning', in Cohen and Sproull (Eds.) Organizational Learning, Thousand Oaks, CA: Sage Publications, pp.430-459.

De Carolis, D. (2002) 'The role of social capital and organizational knowledge in enhancing entrepreneurial opportunities in high-technology environments', in Choo and Bontis (Eds.) The Strategic Management of Intellectual Capital and Organizational Knowledge, New York: Oxford University Press, pp.699-709.

DeNisi, A., Hitt, M. and Jackson, S. (2003) 'The knowledge-based approach to sustainable competitive advantage', in Jackson, Hitt and DeNisi (Eds.) Managing Knowledge for Sustained Competitive Advantage, San Francisco: Jossey-Bass, pp.3-33.

Dess, G., Gupta, A., Hennart, J. and Hill, C. (1995) 'Conducting and integrating strategy research at the international, corporate, and business levels: issues and directions', Journal of Management, Vol. 21, No. 3, pp.357-393.

Dierickx, I. and Cool, K. (1989) 'Asset stock accumulation and sustainability of competitive advantage', Management Science, Vol. 35, No. 12, pp.1504-1511.

Drucker, P. (1993) Post-Capitalist Society, New York: HarperCollins.

Eustace, C. (2000) 'The intangible economy, impact and policy issues', Report of the European High Level Expert Group on the Intangible Economy, European Commission, Luxembourg: Eur-Op, October.

Foss, N. (1997) Resources, Firms and Strategies: A Reader in the Resource-Based Perspective, Oxford: Oxford University Press.

Fulk, J. and DeSanctis, G. (1995) 'Electronic communication and changing organizational forms', Organization Science, Vol. 6, No. 4, pp.337-349.

Garud, R. and Kumaraswamy, A. (2002) 'Technological and organizational designs for realizing economies of substitution', in Choo and Bontis (Eds.) The Strategic Management of Intellectual Capital and Organizational Knowledge, New York: Oxford University Press, pp.233-253.

Garvin, D.A. (1998) 'Building a learning organization', Harvard Business Review on Knowledge Management, Boston, MA: Harvard Business School Publishing, pp.47-80.

Geus, A. (1988) 'Planning as learning', Harvard Business Review, March-April, pp.70-74.

Grant, R. (1991) 'A resource-based perspective of competitive advantage', California Management Review, Vol. 33, pp.114-135. 
Grant, R. (1996a) 'Towards a knowledge-based view of the firm', Strategic Management Journal, Vol. 17, pp.109-122.

Grant, R. (1996b) 'Prospering in dynamically competitive environments: organizational capability as knowledge integration', Organization Science, Vol. 7, pp.375-387.

Grant, R. (1997) 'The knowledge-based view of the firm: implications for management practice', Long Range Planning, Vol. 30, No. 3, pp.450-454.

Grant, R. (2002) 'The knowledge-based view of the firm', in Choo and Bontis (Eds.) The Strategic Management of Intellectual Capital and Organizational Knowledge, New York: Oxford University Press, pp.133-148.

Gratton, L. and Ghoshal, S. (2003) 'Managing personal human capital: new ethos for the “volunteer" employee', European Management Journal, Vol. 21, No. 1, pp.1-10.

Gupta, O. and Roos, G. (2001) 'Mergers and acquisitions through an intellectual capital perspective', Journal of Intellectual Capital, Vol. 2, No. 3, pp.297-309.

Guthrie, J. (2001) 'The management, measurement and the reporting of intellectual capital', Journal of Intellectual Capital, Vol. 2, No. 1, pp.27-41.

Hannes, K. and Fjedstad, Ø. (2000) 'Linking intangible resources and competition', European Management Journal, Vol. 18, No. 1, pp.52-62.

Helfat, C. and Peteraf, M. (2003) 'The dynamic resource-based view: capability lifecycles', Strategic Management Journal, Vol. 24, pp.997-1010.

Hiltrop, J. (1999) 'The quest for the best: human resource practices that attract and retain talent', European Management Journal, Vol. 17, No. 4, pp.422-430.

Hitt, M., Bierman, L., Shimizu, K. and Kockhar, R. (2001) 'Direct and moderate effects of human capital on strategy and performance in professional service firms: a resource-based perspective', Academy of Management Review, Vol. 44, No. 1, pp.13-28.

Hoopes, D., Madsen, T. and Walker, G. (2003) 'Guest editor's introduction to the special issue: why is there a resource-based view? Toward a theory of competitive heterogeneity', Strategic Management Journal, Vol. 24, pp.889-902.

Hoskisson, R., Hitt, M., Wan, W. and Yiu, D. (1999) 'Theory and research in strategic management: swings of a pendulum', Journal of Management, Vol. 25, No. 3, pp.417-456.

Huizing, A. and Bouman, W. (2002) 'Knowledge and learning markets and organizations', in Choo and Bontis (Eds.) The Strategic Management of Intellectual Capital and Organizational Knowledge, New York: Oxford University Press, pp.185-204.

Jeong, B. (2002) 'Measurement of human capital input across countries: a method based on the labour's income', Journal of Development Economics, Vol. 67, pp.333-349.

Kim, W. and Mauborgne, R. (1999) 'Strategy, value innovation and the knowledge society', Sloan Management Review, Vol. 40, No. 3, pp.41-54.

King, A. and Zeithaml, C. (2003) 'Measuring organizational knowledge: a conceptual and methodological framework', Strategic Management Journal, Vol. 24, pp.763-772.

Kogut, B. and Zander, U. (1992) 'Knowledge of the firm, combinative capabilities, and the replication of technology', Organization Science, Vol. 3, pp.383-397.

Lei, D., Hitt, M. and Bettis, R. (1996) 'Dynamic core competences through meta-learning and strategic context', Journal of Management, Vol. 22, No. 4, pp.549-569.

Levitt, B. and March, J. (1988) 'Organizational learning', Annual Review of Sociology, Vol. 14, pp.319-340.

Mahoney, J. (1995) 'The management of resources and the resource of management', Journal of Business Research, Vol. 33, No. 2, pp.91-101.

Makadok, R. (2001) 'Toward a synthesis of the resource-based and dynamic-capability views of rent creation', Strategic Management Journal, Vol. 22, pp.387-401. 
Makhija, M. (2003) 'Comparing the resource-based and the market-based views of the firm: empirical evidence from the Czech privatisation', Strategic Management Journal, Vol. 24, pp.433-451.

Malerba, F. and Orsenico, L. (2000) 'Knowledge, innovative activities and industrial evolution', Industrial and Corporate Change, Vol. 9, No. 2, pp.289-314.

Markham, S. (1998) 'The scientific visualization of organizations: a rationale for a new approach to organizational modelling', Decision Sciences, Vol. 29, No. 1, pp.1-23.

Marr, B. (2004) 'Is it impossible to benchmark intellectual capital?', in Bart, Bontis and Head (Eds.) Conference Proceedings of the 25th McMaster World Congress, Hamilton, Canada: MWC, January.

Mata, F., Fuerst, W. and Barney, J. (1995) 'Information Technology and sustained competitive advantage: a resource-based analysis', MIS Quarterly, December, pp.487-505.

Mathews, J. (2003) 'Competitive dynamics and economic learning: an extended resource-based view', Industrial and Corporate Change, Vol. 12, No. 1, pp.115-145.

Matusik, S. and Hill, C. (1998) 'The utilization of contingent work, knowledge, and competitive advantage', Academy of Management Review, Vol. 23, No. 4, pp.680-697.

McEvily, S. and Chakravarthy, B. (2002) 'The persistence of knowledge-based advantage: an empirical test for product performance and technological knowledge', Strategic Management Journal, Vol. 23, pp.285-305.

Miller, K. (2002) 'Knowledge inventories and managerial myopia', Strategic Management Journal, Vol. 23, pp.689-706.

Montgomery, C. and Wernerfelt, B. (1988) 'Diversification, Ricardian rents, and Tobin's q', Rand Journal of Economics, Vol. 19, No. 4, pp.623-632.

Nelson, R. and Winter, S. (1982) An Evolutionary Theory of Economic Change, Cambridge, MA: Belknap Press.

Nonaka, I. (1991) 'The knowledge-creating company', Harvard Business Review, NovemberDecember, pp.96-104.

Nonaka, I. and Takeuchi, H. (1995) The Knowledge Creating Company: How Japanese Companies Create the Dynamics of Innovation, New York: Oxford University Press.

OECD (1999) 'Economic outlook: measuring and reporting intellectual capital', Programme Notes and Background to Technical Meeting and Policy and Strategy Forum, Paris, OECD.

Penrose, E. (1959) The Theory of the Growth of the Firm, Oxford: Basil Blackwell Publisher.

Penrose, E. (1980) The Theory of the Growth of the Firm, Oxford: Basil Blackwell Publisher, 2nd Ed.

Peteraf, M. (1993) 'The cornerstones of competitive advantage: a resource-based view', Strategic Management Journal, Vol. 13, pp.363-380.

Petrick, J., Scherer, R., Brodzinski, J., Quinn, J. and Ainina, M. (1999) 'Global leadership skills and reputational capital: intangible resources for sustainable competitive advantage', Academy of Management Executive, Vol. 13, No. 1, pp.58-69.

Roos, G., Bainbridge, A. and Jacobsen, K. (2001) 'Intellectual capital as a strategic tool', Strategy and Leadership Journal, July-August.

Roos, G., Roos, J., Edvinsson, L. and Dragonetti, N. (1997) Intellectual Capital: Navigating in the New Business Landscape, New York: Macmillan.

Roos, J. (1998) 'Exploring the concept of Intellectual Capital (IC)', Long Range Planning, Vol. 31, pp.150-153.

Rouse, M. and Daellenbach, U. (2002) 'More thinking on research methods for the resource-based perspective', Strategic Management Journal, Vol. 23, pp.963-967.

Rugman, A. and Verbeke, A. (2002) 'Edith's Penrose's contribution to the resource-based view of strategic management', Strategic Management Journal, Vol. 23, pp.769-780. 
Rumelt, R. (1984) 'Towards a strategic theory of the firm', in Lamp (Ed.) Competitive Strategic Management, New Jersey: Prentice Hall.

Rylander, A. and Peppard, J. (2004) 'What is really a knowledge intensive firm? An analysis of the dependent variable', in Bart, Bontis and Head (Eds.) Conference Proceedings of the 25th McMaster World Congress, Hamilton, Canada: MWC, January.

Schein, E. (1985) Organizational Culture and Leadership, San-Francisco: Jossey-Bass.

Senge, P. (1990) The Fifth Discipline - The Art and Practice of The Learning Organization, New York: Doublebay.

Serenko, A. and Bontis, N. (2004) 'Meta-review of knowledge management and intellectual capital literature: citation impact and research productivity rankings', Knowledge and Process Management, Vol. 11, No. 3, pp.185-198.

Seth, A. and Thomas, H. (1994) 'Theories of the firm: implications for strategy research', Journal of Management Studies, March, Vol. 31, No. 2, pp.165-191.

Sirois, C. (1999) 'The knowledge-based society: a perspective on the road ahead', Executive Speeches, August-September, pp.1-4.

Spanos, Y. and Lioukas, S. (2001) 'An examination into the causal logic of rent generation: contrasting porter's competitive strategy framework and the resource-based perspective', Strategic Management Journal, Vol. 22, pp.907-934.

Spender, J. (2002) 'Knowledge, uncertainty and an emergency theory of the firm', in Choo and Bontis (Eds.) The Strategic Management of Intellectual Capital and Organizational Knowledge, New York: Oxford University Press.

Starbuck, W. (1992) 'Learning by knowledge intensive firms', Journal of Management Studies, Vol. 29, No. 6, pp.713-740.

Stewart, T. (1997) Intellectual Capital: The New Wealth of Organizations, New York, NY: Doubleday.

Sveiby, K. (2001) 'A knowledge-based theory of the firm to guide in strategy formulation', Journal of Intellectual Capital, Vol. 2, No. 4, pp.334-358.

Szulanski, G. (2003) Sticky Knowledge - Barriers to Knowing in the Firm, London: Sage Publications Ltd.

Teece, D., Pisano, G. and Shuen, A. (1997) 'Dynamic capabilities and strategic management', Strategic Management Journal, Vol. 18, No. 7, pp.509-534.

Umemoto, K. (2002) 'Managing existing knowledge is not enough', in Choo and Bontis (Eds.) The Strategic Management of Intellectual Capital and Organizational Knowledge, New York: Oxford University Press, pp.463-476.

Volberda, H. (1996) 'Toward the flexible form: how to remain vital in the hypercompetitive environments', Organization Science, Vol. 7, pp.359-374.

Von Krogh, G. and Grand, S. (2002) 'From economic theory towards a knowledge-based theory of the firm', in Choo and Bontis (Eds.) The Strategic Management of Intellectual Capital and Organizational Knowledge, New York: Oxford University Press, pp.163-184.

Wernerfelt, B. (1984) 'A resource-based view of the firm', Strategic Management Journal, Vol. 5, No. 2, pp.171-180.

Wiklund, J. and Shepherd, D. (2003) 'Knowledge-based resources, entrepreneurial orientation, and the performance of small and medium-sized businesses', Strategic Management Journal, Vol. 24, pp.1307-1314.

Winter, S. (1987) 'Knowledge and competence as strategic assets', in D. Teece (Ed.) The Competitive Challenge: Strategies of Industrial Innovation and Renewal, Cambridge, MA: Ballinger, pp.159-184.

Winter, S. (2003) 'Understanding dynamic capabilities', Strategic Management Journal, Vol. 24, pp.991-995. 
Winter, S. and Szulanski, G. (2002) 'Replication of organizational routines: conceptualizing the exploitation of knowledge assets', in Choo and Bontis (Eds.) The Strategic Management of Intellectual Capital and Organizational Knowledge, New York: Oxford University Press, pp.207-221.

Zack, M. (2002) 'Developing a knowledge strategy', in Choo and Bontis (Eds.) The Strategic Management of Intellectual Capital and Organizational Knowledge, New York: Oxford University Press, pp.255-276.

Zack, M. (2003) 'Rethinking the knowledge-based organization', Sloan Management Review, Vol. 44, No. 4, pp.67-71.

\section{Bibliography}

Birchall, D. and Tovstiga, G. (1999) 'The strategic potential of a firm's knowledge portfolio', Journal of General Management, Vol. 25, No. 1, pp.1-16.

Davenport, T. and Pruzac, L. (2000) Working Knowledge: How Organizations Manage What They Know, Boston: Harvard Business Scholl Press.

Priem, R. and Butler, J. (2001a) 'Is the resource-based "view" a useful perspective for strategic management research?', Academy of Management Review, Vol. 28, No. 1, pp.22-40.

Priem, R. and Butler, J. (2001b) 'Tautology in the resource-based view and the implications of externally determined resource value: further comments', Academy of Management Review, Vol. 26, No. 1, pp.57-66.

Reinhardt, R., Bornemann, M., Pawlowsky, P. and Schneider, U. (2003) 'Intellectual capital and knowledge management: perspectives on measuring knowledge', in Dierkes, Antal, Child and Nonaka (Eds.) Handbook of Organizational Learning and Knowledge, Oxford: Oxford University Press, pp.794-820.

Seleim, A., Ashour, A. and Bontis, N. (2004) 'Intellectual capital in Egyptian software firms', The Learning Organization: An International Journal, Vol. 11, Nos. 4-5, pp.332-346.

Silva, C. and Castro, C. (2003) 'Comportamentos e Resistências na Era do Conhecimento', in Silva and Neves (Orgs.) Gestão de Empresas na Era do Conhecimento, Lisboa: Edições Sílabo, pp.83-110.

Stewart, T. (1998) 'Knowledge, the appreciating commodity', Fortune, October, pp.199-200.

Wenger, E. and Snyder, W. (2001) 'Communities of practice - the organizational frontier', Harvard Business Review on Organizational Learning, Boston, MA: Harvard Business School Publishing, pp.1-19. 